\title{
QUALITY OF LIFE AND QUALITY OF ENVIRONMENT IN CZECHIA IN THE PERIOD OF THE COVID-19 PANDEMIC
}

\author{
František Murgaš*, František Petrovič ${ }^{* *}$ \\ * Technical University in Liberec, Faculty of Science, Humanities and Education, Department of Geography, \\ Studentská 2, Liberec, 461 17, Czechia, fmtren@gmail.com \\ ** Constantine the Philosopher University in Nitra, Faculty of Natural Sciences, Department of Ecology \\ and Environmental Sciences, Nitra, 949 74, Slovakia, fpetrovic@ukf.sk
}

\begin{abstract}
Quality of life and quality of environment in Czechia in the period of the COVID-19 pandemic

The paper is aimed at the impact of COVID-19 on the quality of living and environment in Czechia. The pandemic has affected almost all countries with varying intensity. Its manifestations in the form of the number of infected and dead in the absence of an effective cure has provoked a reaction from governments, which has significantly affected people's lives and thus its quality. Due to its connection with the pandemic, the importance of physical space has increased, therefore attention is also focused on the impact of the pandemic on the quality of the environment. The authors, who deal with the impact of natural disasters on peoples' quality of life, have stated a decrease in the quality of life after these disasters and the subsequent post-traumatic stress disorder. Although a pandemic differs from natural disasters such as earthquakes, hurricanes or fires in its duration and the size of the affected population, its negative impact on the quality of life and the quality of space can be expected, and a hypothesis is formulated in this sense. The aim of the article is to explore the evaluation of our lives and the evaluation of the environment, measuring their quality and finding correlations at the time of the outbreak and the culmination of COVID-19. The research based on a questionnaires was conducted in the region of central and northern Bohemia (Czechia) among the population over the age of 18 and has brought surprising results.
\end{abstract}

Key words: quality of life, quality of environment, quality of place, COVID-19, questionnaire survey, Czechia

\section{INTRODUCTION}

In the spring months of 2020, an epidemic of respiratory disease broke out, which was named COVID-19. In a short time, it affected almost all countries of the world, so the World Health Organization called it a pandemic. The increase in the number of infected and dead, along with the lack of effective equipment - a simple type of face mask or a complex type of ventilator - led to governments taking hard measures.

Teaching at all types of schools, including universities, was cancelled. Closed shops with the exception of food shops, drugstores, pharmacies and petrol stations, a ban on all mass sports and other events, including masses and religious ceremonies, a ban on flights, international train and bus connections, and the closure of borders and quarantine in individual countries have had significant social and economic consequences. Large industrial corporations stopped producing, tourism was basically non-existent. The result is a crisis that a generation of people born after World War II have not experienced (Dzúrová and Jarolímek 2020). In World War I and II, the war conflict events affected millions of people, but not all continents 
were affected. Due to globalization, the current pandemic affects people of all continents to varying degrees.

The described crisis has significantly affected our lives, and thus its quality. Researchers therefore deal with the impact of various natural disasters on the quality of life - Norwegians affected by a tsunami (Nygaard and Trond 2012), rural Greeks living in areas with a wildfire disaster (Papanikolaou et al. 2012), Slovaks living in the micro-region affected by flooding (Jakubcová et al. 2016), residents of Taiwan affected by an earthquake (Cui and Han 2018), Americans affected by the hurricane (Barile et al. 2019). Ardalan et al. (2010) examined the post-disaster quality of life of survivors five years after an earthquake in Iran. According to $\mathrm{Ny}-$ gaard and Trond (2012) natural disasters and subsequent post-traumatic stress disorder decrease the quality of life.

The aim of the paper is to explore the evaluation of the life and environment of the inhabitants in one region of Czechia, the measurement of their quality and the search for links in the form of correlations at the time of the outbreak and the culmination of COVID-19. We express the hypothesis: It can be expected that the anxiety, worries, or depression accompanying the current pandemic will result in a lower, in some cases low, assessment of the quality of life of the population. The research was conducted in the region of northern and central Bohemia (Czechia) among the population older than 18 years $(\mathrm{N}=311)$. To measure the quality of life and related phenomena, a questionnaire survey was conducted with most questions quantifiable on a scale of $0-10$. It intentionally lacks any mention of the crisis or the limitations or other negatives that have accompanied the crisis.

\section{THEORETICAL BACKGROUND}

\section{Quality of life}

If any scientific text is to produce valid results, the basic concepts must be described. Therefore, at the beginning we clarify what we are focused on when we explore the quality of life. Quality of life is a concept by which people in the current period of late modernity cognitively and emotionally evaluate satisfaction with their lives. When satisfaction prevails in the evaluation, the result is a feeling of well-being, when dissatisfaction prevails in the evaluation, the result is ill-being. Happiness is the highest attainable level of satisfaction with life. Quality of life has two dimensions - subjective (personal), and objective (spatial). This statement is the only consensus prevailing among researchers, focused on quality of life. The problem with the research of quality of life, as well as other social concepts, is the terminological chaos, manifested at least in the fact that it makes comparison impossible. Quality of life is not the only term expressing satisfaction with life, others are well-being, welfare, or happiness.

In addition to the term well-being, adjectives such as the mental, psychological, economic, subjective, objective or well-being of nations are added. The argument against identifying well-being with quality of life is trivial - if identification were valid, what would ill-being be? Quality of life cannot even be identified with happiness (Layard 2005). The identification of quality of life, well-being and happiness is the result of the lagging behind of their epistemology in comparison with several scientific articles, focused on partial applied approaches. Quality of life is significantly associated with the term 'good life' (Veenhoven 2000). According to 
Murgaš and Klobučník (2016) the issue of quality of life is the issue of values. The outlined conceptualization of quality of life can be summarized in the statement that it represents an evaluation of satisfaction with life in comparison with the idea of a good life lived in a good place, which is held by each individual. Quality of life is therefore a holistic expression of both its dimensions - satisfaction with life and quality of place. In this sense, it can be defined as an assessment of the good life lived in a good place. Among others geographical research in Slovakia also responded to the growth of interest in the quality of life, both at the conceptual level (e.g. Ira and Andráško 2007, Ira 2012 and Murgaš 2016) and at the application level (e.g. Ira et al. 2006, Murgaš 2009, Ira 2015 and Rišová and Pouš 2018).

In this paper, we understand quality of life holistically as satisfaction with life lived in a physical space. This space is reflected in the quality of external conditions for living a good life. An important attribute of space is the environment.

\section{Environment}

The Cambridge Dictionary (2019) defines environment as: "the air, water and land in or on which people, animals, and plants live." This definition is based on the frequent understanding of the area as the environment. However, in recent decades, in addition to 'environmental hazards', the term 'environment' has also appeared in new terms such as 'environmental economics', 'environment justice' or 'environmental psychology.' Mankind has changed the flood natural landscape to such an extent that if it wants to use the current cultural landscape, it must protect and manage it (Petrovič et al. 2017). From the aspect of quality of life, we are not interested in the physical parameters of air, water and soil, but in their complex effect on life satisfaction. This means assessing the environment from the perspective of human geography, which is focused on the built environment (Sassi 2016). According to Eden $(2009$, p. 505) from the point of view of human geography, "we can group these diverse ways of thinking about the environment into three: the environment as a powerful resource outside society; the environment as fragile and damaged by society; and the environment as part of society." Zimmerer (2017, p. 4) uses the term human-environmental geography, considering its nine main areas, including social-ecological and coupled human-environment systems. This paper deals with the quality of the environment in Czechia and the interest of the inhabitants in it.

The position of Czechia in measuring the quality of life in the country

Czechia is one of the countries in the region of Central and Eastern Europe that has undergone a major transformation of political, social, and economic development, referred to as a transition. Together with some other countries in the region, it is referred to as a post-transit country (i.e. a country in which the transition is already completed). However, the development in the region is complicated, so the inhabitants of these countries often behave differently compared to the inhabitants of the countries of "old" Europe, an example can be its refusal to accept migrants. Czechia, is in the first place in most measurements of social and economic indicators when compared to these countries, and in a few cases second after Slovenia.

In 2018, according to Eurostat (2019b), its GDP per capita in Purchasing Power Standards reached $91 \%$ of the EU average, i.e. the same as Spain and more than Portugal (77\%) and Greece (69\%). According to data from the Czech Institute of Empirical Research (STEM) from November 2019, 64\% of the population is satis- 
fied with the development of the country after 1989, the most since the beginning of these surveys (STEM 2019). At the beginning of 2020, according to Eurostat data, Czechia maintained the lowest unemployment rate in Europe. Czechia is a member of the V4 regional group (Visegrad Group), together with Slovakia, Poland, and Hungary. For this reason, some data is given for other V4 countries.

Quality of life at a country level is measured by subjective or objective indicators (in some measurements, e. g. Eurostat - 2019c uses the term dimension) or their combination, Tab. 1 shows their examples. To measure the quality of life in the settlements Cárcaba et al. (2016) in Spain and Murgaš and Klobučník (2016) in Czechia applied a set of objective indicators available from statistical data.

Garau and Pavan (2018) measured the quality of urban life in Italy using a combination of twelve objective and subjective indicators, the same as Eurostat (2019c) did. Gallup, whose data is taken over by the World Happiness Report since 2020 (Helliwell et al., eds. 2020), measured Well-Being Indexes using questionnaires. Respondents answer face to face or by telephone survey, giving values on a Cantril scale of $0-10$. A similar procedure was used by Petrovič and Murgaš (2020) in determining the quality of life and related phenomena in Czechia.

\section{Tab. 1. Domains and indicators of quality of life}

\begin{tabular}{|c|c|c|c|}
\hline \multicolumn{4}{|c|}{ Domains/Indicators of quality of life by some authors } \\
\hline $\begin{array}{c}\text { Murgaš and Klobučník } \\
(2016)\end{array}$ & $\begin{array}{c}\text { Cárcaba et al. } \\
(2017)\end{array}$ & $\begin{array}{c}\text { Garau and Pavan } \\
(2018)\end{array}$ & $\begin{array}{c}\text { Petrovič and Murgaš } \\
(2020)\end{array}$ \\
\hline $\begin{array}{l}\text { Life expectancy } \\
\text { at birth - males }\end{array}$ & $\begin{array}{l}\text { Material living } \\
\text { conditions }\end{array}$ & $\begin{array}{l}\text { Flexibility and } \\
\text { functionality }\end{array}$ & Quality of place \\
\hline $\begin{array}{l}\text { Life expectancy } \\
\text { at birth - females }\end{array}$ & & $\begin{array}{l}\text { Minimum service } \\
\text { provided }\end{array}$ & Happiness \\
\hline Suicides & Personal activities & Security system & Safety \\
\hline Mortality & $\begin{array}{l}\text { Economic and physical } \\
\text { safety }\end{array}$ & Accessibility & \\
\hline Birth rate & $\begin{array}{l}\text { Governance and } \\
\text { political voice }\end{array}$ & Emotional wellbeing & \\
\hline Divorce rate & Social interaction & Social wellbeing & Trust \\
\hline Education & Education & $\begin{array}{l}\text { Smart crime preven- } \\
\text { tion }\end{array}$ & \\
\hline Unemployment rate & Health & $\begin{array}{l}\text { Environment } \\
\text { characteristics }\end{array}$ & Health \\
\hline Emission balance & Environment & Soil pollution & Environment \\
\hline Generativity & & $\begin{array}{l}\text { Built environment } \\
\text { characteristics }\end{array}$ & \\
\hline
\end{tabular}

Source: adapted from cited authors.

Objective indicators have several advantages, including the ability to create a time series. The problem is the level of their connection with subjective indicators. Murgaš and Klobučník (2016) report Pearson's coefficient of correlation between 
subjective and objective indicators at the level of districts of Czechia (-0.19), which according to the verbal interpretation of correlation evaluation factors (de Vaus 2002) means an insignificant small correlation. In addition, as it turned out, in the districts with the lowest values of the quality of life index measured by objective indicators, the values of subjective quality of life based on questionnaire survey were 'higher than they should be' and vice versa, in the districts with high values of the quality of life index measured by objective indicators, the values of subjective quality of life, as determined by the questionnaire survey, were 'lower than they should be'.

In fact, this meant that people in objectively low-quality districts subjectively felt better and people in objectively high-quality districts felt worse than they 'should feel'. From the point of view of a holistic, i.e. comprehensive approach to quality of life, two solutions to this problem are possible. The first is the inclusion of satisfaction with life or well-being, as determined by a questionnaire survey on the indicators of the Quality of Life Index (Garau and Pavan 2018). But then an epistemological problem arises. The subjective dimension of quality of life is considered more important than the objective dimension, but the three subjective indicators among the 12 indicators do not correspond to this. These three indicators would have to be assigned a weight that would be more than $50 \%$ of the sum of the weights of all indicators. The second possible solution is to include the determination of the quality of life in a subjective assessment of the quality of the place in which people experience their lives. The evaluation is quantified on a scale of $0-$ 10. This procedure is also applied to this paper.

In this article we focus on the position of Czechia in measuring the quality of life in countries. We examine the position in the most well-known measurements worldwide (Tab. 2) or European (Tabs. 3 and 4). Value in Tab. 2 is the average of six variables, the value in Tab. 4 is the average of respondents' answers on a scale of $0-10$ for a given country. The tables always show the country in first place, Czechia and other V4 countries and the country in the last place in the measurement.

Tab. 2. Ranking of happiness 2017 - 2019, selected countries

\begin{tabular}{rcc}
\hline Rank & Country & Value \\
\hline 1 & Finland & 7.809 \\
19 & Czechia & 6.911 \\
37 & Slovakia & 6.281 \\
43 & Poland & 6.186 \\
53 & Hungary & 6.000 \\
153 & Afghanistan & 2.567 \\
\hline
\end{tabular}

Source: Helliwell et al. (2020)

The position of Czechia in the World Happiness Report expresses the country's position at a global level. The report has been published since 2012, in the first measurement for the years $2007-2010$, the country was in 38th place. In other measurements it took 39th, 31st, 27th, 23rd, 21st and in the measurement for 2018, 
19th place. In this measurement, the World Happiness Report also contains measurements in the cities for the first time. Current Life Evaluation where Prague took 44th place and Helsinki was first (Helliwell et al. 2020). Its position within comparable countries has a greater informative value, which is why we present the OECD Better Life Index measurement (Tab. 3) and the measurement in European countries (Tab. 4).

Tab. 3. Ranking of OECD Better Life Index, selected countries

\begin{tabular}{clc}
\hline Rank & Country & Value \\
\hline $1-3$ & Denmark & 7.6 \\
$1-3$ & Finland & 7.6 \\
$1-3$ & Norway & 7.6 \\
19 & Czechia & 6.7 \\
22 & Slovakia & 6.2 \\
23 & Poland & 6.1 \\
28 & Hungary & 5.6 \\
40 & South Africa & 4.7 \\
\hline
\end{tabular}

Tab. 4. Ranking in Overall life satisfaction in 2018, selected European countries

\begin{tabular}{clc}
\hline Rank & \multicolumn{1}{c}{ Country } & Value \\
\hline 1 & Ireland & 8.1 \\
7 & Poland & 7.8 \\
14 & Czechia & 7.4 \\
22 & Slovakia & 7.1 \\
26 & Hungary & 6.5 \\
31 & Bulgaria & 5.4 \\
\hline
\end{tabular}

Source: Eurostat (2020).

Source: OECD (2020).

The structure of satisfaction with life of the member states of the European Union, Norway and Switzerland is expressed in Fig. 1.

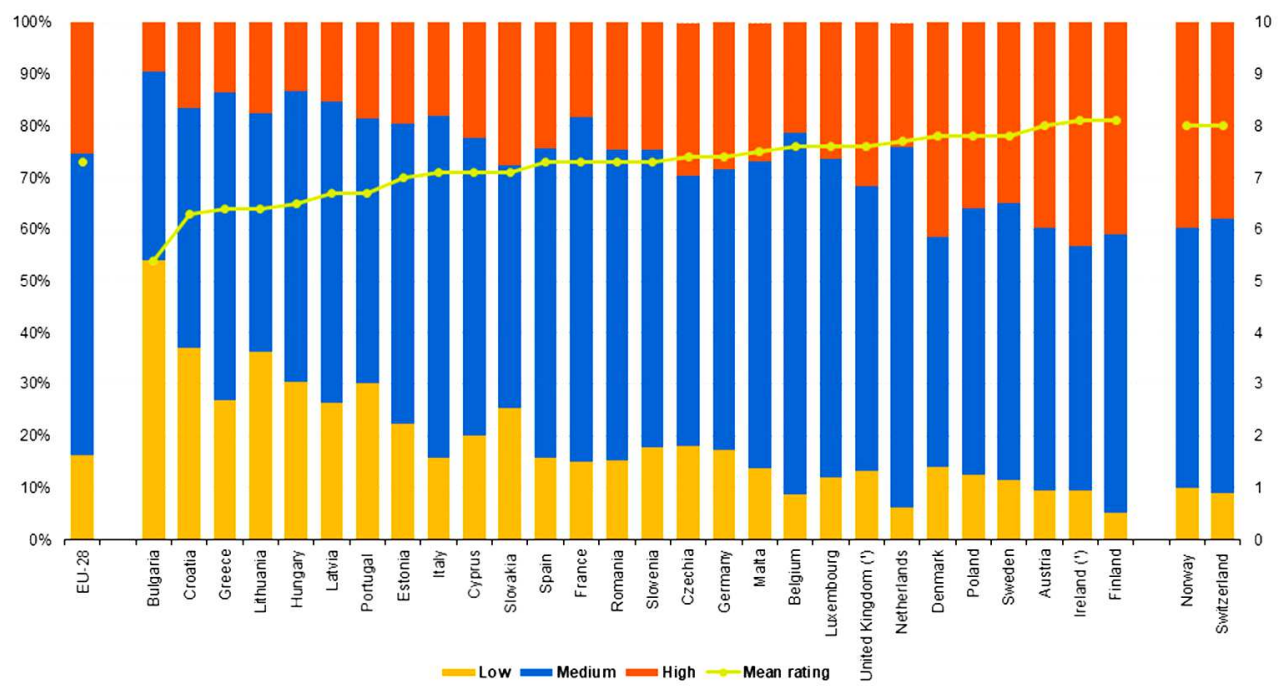

Fig. 1 Satisfaction with life in European countries

Left axis: \% of population by satisfaction level, right axis: mean rating.

Source: Eurostat (2019a). 


\section{QUALITY OF LIFE IN CZECHIA}

In the years $2003-2015$, the quality of life in Czechia, measured on a 5-point Likert scale, stagnated (Murgaš 2019). In the years 2016 - 2019, the quality of life improved (Tab. 5), the positive development is confirmed by the value of 7.38 determined by measuring on a scale of $0-10$ in 2019 (Petrovič and Murgaš 2020) or the value of life satisfaction 7.4, reported by Eurostat (2020).

Tab. 5. Development of life satisfaction in the years $2016-2019$

\begin{tabular}{lcrrrrr}
\hline \multirow{2}{*}{ Satisfaction } & \multicolumn{7}{c}{ Average values } \\
\cline { 2 - 7 } & $2003-2015$ & 2016 & 2017 & 2018 & 2019 & $2016-2019$ \\
\hline Very satisfied & 11.0 & 14.5 & 13.9 & 15.5 & 15.8 & 14.9 \\
Satisfied & 49.7 & 51.5 & 52.3 & 51.6 & 50.1 & 51.4 \\
Satisfied/dissatisfied & 24.3 & 22.1 & 22.8 & 22.1 & 23.3 & 22.6 \\
Dissatisfied & 12.0 & 10.0 & 9.4 & 9.3 & 8.5 & 9.3 \\
Very dissatisfied & 3.0 & 1.9 & 1.6 & 1.5 & 1.0 & 1.5 \\
\hline
\end{tabular}

Source: adapted from Murgaš (2019), CVVM (2020a).

\section{QUALITY OF ENVIRONMENT}

In relation to the quality of life, one attribute of the environment is important and thus its quality is expressed by the quality of conditions for living a good life. Murgaš and Klobučník (2016) conceptualize it as the quality of a place.

The paper focuses on the evaluation of life satisfaction and environmental satisfaction at the time of COVID-19. The environment is an important part of the quality of a place or quality of life, in its measurement it is usually one of the indicators or it is a domain (Streimikiene 2014, Murgaš and Böhm 2015). In the measurements of the years 2006 - 2019, more than $50 \%$ of the population of the Czechia was always interested in the environment (Tab. 6).

Tab. 6. The interest of the inhabitants of the Czechia in environmental information (2006-2019)

\begin{tabular}{cccccc}
\hline \multicolumn{5}{c}{ The interest in environmental information (\%) } \\
\cline { 1 - 5 } Year & \multicolumn{4}{c}{ Interested } & \multicolumn{3}{c}{ Not interested } & \multirow{2}{*}{ Doesn't know } \\
\cline { 2 - 5 } 2006 & Significantly & Rather & Rather & Significantly & 2 \\
2007 & 13 & 56 & 26 & 3 & 1 \\
2008 & 13 & 54 & 29 & 3 & 1 \\
2009 & 11 & 48 & 35 & 5 & 1 \\
2011 & 15 & 53 & 28 & 3 & 1 \\
2012 & 10 & 49 & 35 & 5 & 1 \\
2013 & 10 & 49 & 35 & 5 & 1 \\
2014 & 13 & 49 & 32 & 5 & 1 \\
2015 & 9 & 52 & 33 & 5 & 1 \\
2016 & 8 & 51 & 36 & 4 & 2 \\
2017 & 9 & 48 & 36 & 5 & 1 \\
2018 & 7 & 45 & 42 & 5 & 0 \\
2019 & 10 & 47 & 37 & 6 & 1 \\
\hline
\end{tabular}

Source: adapted from CVVM (2019). 
According to the measurement of quality of life from 2019, the value of satisfaction with the environment on a scale of $0-10$ in the Czechia is 7.13. The figures of Pearson's correlation coefficient of satisfaction with the environment and other variables related to quality of life are presented in Tab. 7. Tab. 7. Correlation of environmental quality with quality of life and related
phenomena

\begin{tabular}{llc}
\hline & Correlation & Value \\
\hline \multirow{5}{*}{ Environment } & Quality of life & 0.29 \\
& Quality of place & 0.59 \\
& Safety & 0.59 \\
& Health & 0.25 \\
& Trust & 0.23 \\
\hline
\end{tabular}

Source: adapted from Petrovič and Murgaš (2020).

According to the verbal evaluation of relationships (de Vaus 2002), the correlation of environmental quality with the quality of a place and one of its parameters - safety - is 'close', the correlation with quality of life and other phenomena is not very close. The difference between the correlation of the quality of the environment and the quality of the place on the one hand, and on the other hand the quality of life is another argument for the inevitability to deal with the place when we want to express the quality of life.

\section{MEASURING QUALITY OF LIFE}

Quality of life and related phenomena quality of place, environment, happiness, safety, trust, and health are measured through responses to questions using the Cantril scale ranging from 0 to 10 . Data is obtained face-to-face and via the Internet. Data collection took place in the months March - April 2020 for the population over 18 years of age in the region of northern and central Czechia. The number of respondents $(\mathrm{N}=311)$ is influenced by the length of the research and its duration in the period of the COVID-19 pandemic.

We compare the achieved results in 2020 to the measurement in 2019, which took place under the same conditions (Tab. 8).

Tab. 8. Values of quality of life, quality of place, environment, happiness, safety, trust and health in years 2020 and 2019

\begin{tabular}{cccccccc}
\hline Year & Variables & Quality of place & Quality of life & Environment & Safety & Trust & Health \\
\hline \multirow{2}{*}{2020} & men & 7.6 & 7.3 & 7.4 & 7.9 & 5.7 & 7.7 \\
& women & 7.9 & 7.9 & 7.8 & 8.2 & 6.1 & 8.7 \\
& average & 7.7 & 7.6 & 7.6 & 8.1 & 5.9 & 8.2 \\
\hline \multirow{2}{*}{2019} & average & 7.0 & 7.4 & 7.2 & 8.0 & 6.0 & 8.6 \\
\hline
\end{tabular}

Source: own research and Petrovič and Murgaš (2020). 
In addition to measuring the values of quality of life, quality of place and the quality of the environment and other variables, we are also interested in the correlation between them. As for male respondents (Tab. 9), the correlation between quality of life and happiness are classified as close and medium, the correlations between quality of life and place, environment and health are classified as medium. Quality of life correlates with other variables at the small and very small levels.

Tab. 9. Correlations matrix for variables quality of life, quality of place, environment, happiness, safety, trust, and health (2020, male respondents)

\begin{tabular}{lcccccc}
\hline \multicolumn{1}{c}{ Variables } & Quality of place & Quality of life & Environment & Safety & Health & Trust \\
\hline Quality of place & $\mathrm{x}$ & & & & & \\
Quality of life & 0.47 & $\mathrm{x}$ & & & & \\
Environment & 0.50 & 0.42 & $\mathrm{x}$ & & & \\
Safety & 0.16 & 0.12 & 0.21 & $\mathrm{x}$ & & \\
Health & 0.13 & 0.29 & 0.12 & 0.34 & $\mathrm{x}$ & \\
Trust & -0.11 & 0.18 & 0.17 & 0.16 & 0.02 & $\mathrm{x}$ \\
\hline
\end{tabular}

Source: own research.

Data obtained from female respondents show (Tab. 10) that, quality of life correlates with happiness at the large level, with quality of place, environment, and safety at a medium level. The correlation of quality of life with other variables is at a low to very low level.

Tab. 10. Correlations matrix for variables quality of life, quality of place, environment, happiness, safety, trust, and health $(2020$, female respondents)

\begin{tabular}{lcccccc}
\hline \multicolumn{1}{c}{ Variables } & Quality of place & Quality of life & Environment & Safety & Health & Trust \\
\hline Quality of place & $\mathrm{x}$ & & & & & \\
Quality of life & 0.44 & $\mathrm{x}$ & & & & \\
Environment & 0.50 & 0.38 & $\mathrm{x}$ & & & \\
Safety & 0.23 & 0.39 & 0.43 & $\mathrm{x}$ & & \\
Health & 0.16 & 0.35 & 0.29 & 0.66 & $\mathrm{x}$ & \\
Trust & -0.15 & -0.12 & -0.02 & 0.09 & 0.06 & $\mathrm{x}$ \\
\hline
\end{tabular}

Source: own research.

\section{RESULTS}

There are several key findings from measuring the quality of life at the time of COVID-19:

1) The quality of life assessed by male and female respondents is high. The hypothesis assumed that anxiety, worries or depression accompanying the current 
pandemic will be reflected in a lower, in some cases low assessment of the population's quality of life has not been confirmed.

2) The average value of quality of life in 2020 (7.65) is slightly lower than the average value of quality of life (7.74), measured in 2019. The value of quality of life assessed by female respondents (7.93) is higher than the average value of quality of life (7.74) measured in 2019, however, the value of the quality of life assessed by male respondents (7.38) is lower than the average value of the quality of life (7.74) measured in 2019.

3) The quality of life assessed by female respondents (7.93) is higher than the quality of life assessed by men (7.38). This statement also applies to the other variables examined.

4) The quality of the environment in 2020 (7.67) is higher than the average value of the quality of the environment (7.16), measured in 2019.

5) The values of place quality are also higher (average -7.74 , male respondents -7.60 and female respondents -7.89$)$ in comparison to the average value of place quality (6.96) measured in 2019 (Petrovič and Murgaš 2020).

6) As far as male respondents Pearson's correlation coefficient of quality of life is highest for happiness (0.50), environment (0.43) and health (0.32). Analyses of questionnaires collected from female respondents showed that Pearson's quality of life correlation coefficient is highest for happiness $(0.59)$, environment $(0.37)$ and safety (0.36).

\section{DISCUSSION}

Measuring the quality of life during the period of COVID-19 in Czechia yielded surprisingly high values of quality of life, quality of place, quality of the environment, happiness, and other related phenomena in addition to trust. The expectation of lower to low values of measured variables, expressed in the hypothesis, was not confirmed. The informative value of measuring the quality of life is limited by the fact that the research took place in only one of the regions of Czechia. During the review process of this article the results of the research 'Satisfaction with various aspects of personal life' were published. Total life satisfaction was measured on a scale from 1 to 11, where a value of 1 represented the lowest and a value of 11 the highest life satisfaction. The survey conducted at the level of regions of Czechia (1,043 respondents) took place in May 2020, at the time of the COVID-19 pandemic. The result of the measurement shows that the value of average satisfaction is 8.3. Dissatisfaction (value $1-4$ ) was stated by $5 \%$ of respondents, medium satisfaction (value $5-8$ ) by $40 \%$ of respondents and high level of satisfaction (values 9 - 11) was declared by 55\% of respondents (CVVM 2020b). From these measured values of satisfaction with life, it follows that the values of quality of life that we found in the region of northern and central Czechia can be considered valid.

Measurements in other countries will show whether the measured values in the Czechia are isolated or whether the improvement in quality in developed countries has not been interrupted even by a pandemic.

In the case of the validity of the first alternative, the improvement of the quality of life of the population in Czechia even in the time of coronavirus will strengthen the specificity of the position of this country, determined culturally and geographically (Murgaš 2019). If the second alternative is true, then the statement about the 
negative impact of natural disasters (Nygaard and Trond 2012) on the quality of life in the case of COVID-19 will not apply.

In April 2020 the American Monmouth University Polling Institute published "the Garden State Quality of Life Index", focused on quality of life in the State of New Jersey. The reason why we mention measuring the quality of life in one of the American states is its results. On a scale from -100 to +100 , the value of the index in April 2020 was +37, the highest since the first measurement in December 2010, the lowest $(+13)$ in February 2019. The value of the index for men was +34 and for women +41 in April 2020 (Murray 2020). In New Jersey, as in the studied region of northern and central Bohemia, the quality of life increased during the pandemic, more for women than for men.

\section{CONCLUSION}

The paper is focused on examining the quality of life and the quality of the environment along with other phenomena related to these qualities - quality of place, happiness, health, safety, and trust. The research was conducted in Czechia on a sample of the population over 18 years of age at the time of the outbreak, peak and regression of the first phase of the respiratory disease COVID-19. The hypothesis was formulated: 'It can be expected that the anxiety, worries, or depression accompanying the current pandemic will result in a lower, and in some cases low, assessment of the population's quality of life.'

The paper outlines the quality of life, the environment, the position of Czechia in measuring the quality of life compared to European countries, the quality of life in Czechia and the quality of the environment. Measurements on the Cantril scale 0 - 10 yielded surprisingly good, and not only average values of quality of life (7.65), but also environment (7.67), as well as quality of the place (7.74), happiness (7.49), safety (8.18), trust (6.10) and health (8.22). The hypothesis was not confirmed. The measured values for the same variables are even higher than the values obtained in 2019. Only the values of quality of life and happiness were slightly higher in 2019. The higher values of measured data obtained from female respondents for all variables can also be considered surprising.

The authors would like to thank two anonymous reviewers who have made a significant contribution to the quality of the paper.

This work was supported by the project VEGA 1/0706/20: Urban sustainable development in the 21 st century - assessment of key factors, planning approaches and environmental relationships.

\section{REFERENCES}

ARDALAN, A., MAZAHERI, M., VANROOYEN, M. H. MOWAFI, H., NEDJAT, S., HOLAKOUIE NAIENI, K., RUSSEL, M. (2010). Post-disaster quality of life among older survivors five years after the Bam earthquake: implications for recovery policy. Ageing \& Society, 31, 2, 179-196. DOI: https://doi.org/10.1017/S0144686 X10000772.

BARILE, J. P., BINDER, S. B., BAKER, C. K. (2019). Recovering after a Natural Disaster: Differences in Quality of Life across Three Communities after Hurricane Sandy. Applied Research in Quality Life. 15, 1151-1159. DOI: https://doi.org/10.1007/s11482019-09722-3.

CAMBRIDGE DICTIONARY (2019). Environment, [Online]. Available: https:// dictionary.cambridge.org/ dictionary/english/environment. [Accessed 24 march 2020]. 
CÁRCABA, A., GONZÁLES, E., VENTURA, J. (2016). Social progress in Spanish municipalities (2001 - 2011). Applied Research in Quality of Life, 12, 997-1019. DOI: https://doi.org/10.1007/s11482-016-9502-7.

CUI, K., HAN, Z. (2018). Association between disaster experience and quality of life: the mediating role of disaster risk perception, Quality of Life Research, 28, 509-513. DOI: https://doi.org/10.1007/s11136-018-2011-4.

CVVM (2019). Hodnocení stavu životního prostředí - květen 2019. Tisková správa. Praha

(Centrum pro výzkum veřejného mínění), [Online]. Available: https://cvvm.soc.cas.cz/ media/comform2content /documents/c2/a 4962/f9/oe190624.pdf [Accessed 15 February 2020].

CVVM (2020a). Časové řady vybraných otázek z výzkumu naše společnost. Spokojenost se životem. Praha (Centrum pro výzkum veřejného mínění). [Online]. Available: https:// cvvmapp.soc.cas.cz/\#question13. [Accessed 10 April 2020].

CVVM (2020b)._Spokojenost s různými aspekty osobního života - Naše společnost - speciál - květen 2020. Tisková správa. Praha (Centrum pro výzkum veřejného mínění), [Online]. Available: https://cvvm.soc.cas.cz/media/com form 2 content/documents/c2/ a5213/f9/ov200618.pdf [Accessed 2 February 2020].

De VAUS, D. (2002). Surveys in Social Research. London (Routledge).

DZÚROVÁ, D., JAROLÍMEK, J. (2020). Šíření pandemie COVID-19 napříč geografickými i sociálními hranicemi: dokážeme mu čelit? Geografie, 125, 1-20. DOI: https:// doi.org/10.37040/geografie2020125010001.

EDEN, S. (2009). Environment. In Kitchin, R., Thrift, N., eds. International Encyclopedia of Human Geography, Amsterdam (Elsevier), pp. 505-516.

EUROSTAT (2019a). Quality of life in 2018. How satisfied are people with their lives? Positive trend in subjective well-being. News release 172/2019, 7 November 2019, [Online]. Available: https://ec.europa.eu/eurostat/documents/2995521/10207020/307112019-AP-EN.pdf/f4 523b8 3-f 16 b-251c-2c44-60bd5c0de76d. [Accessed 18 February 2020].

EUROSTAT (2019b). GDP per capita in PPS, [Online]. Available: https://ec.europa.eu/ eurostat/tgm/table.do?tab =table\&init=1\&language=en\&pcode=tec001 14\&plugin=1. [Accessed 18 February 2020].

EUROSTAT (2019c). Quality of life indicators, [Online]. Available: https://ec.europa.eu/ eurostat/statistics-explain ed/ index.php/Quality of life indicators. [Accessed 18 February 2020].

EUROSTAT (2020). Average rating of satisfaction by domain, sex, age and educational attainment level, [Online]. Available: https://appsso.eurostat.ec.europa.eu/nui/ submitViewTableAction.do [Accessed 26 February 2020].

GARAU, CH., PAVAN, V. M. (2018). Evaluating urban quality: Indicators and assessment tools for smart sustainable cities. Sustainability, 10, 575. DOI: 10.3390/su1003 0575 .

HELLIWELL, J. F., LAYARD, R., SACHS, J., De NEVE, J-E., eds. (2020). World Happiness Report 2020. New York (Sustainable Development Solutions Network).

IRA, V., MICHÁLEK, A., PODOLÁK, P. (2006). Kvalita života a životné prostredie človeka. In Mládek, J., Kusendová, D., Marenčáková, J., Podolák, P., Vaňo, B., eds. Demografická analýza Slovenska. Bratislava (Univerzita Komenského), pp. 142-144.

IRA, V., ANDRÁŚKKO, I (2007). Kvalita života z pohl'adu humánnej geografie (Quality of life from the viewpoint of human geography). Geografický časopis, 59, 2, 159-179.

IRA, V. (2012). Kvalita urbánneho života (teoreticko-metodologické poznámky). In Casové a priestorové zmeny regionálnych štruktúr: zborník abstraktov. Bratislava (Geografický ústav SAV), p. 7.

IRA, V. (2015). Petržalka a kvalita života jej obyvatel'ov (subjektívna dimenzia hodnotenia). Zivotné prostredie, 49, 2, 82-86.

JAKUBCOVÁ, A., GREŽO, H., HREŠKOVÁ, A., PETROVIČ, F. (2016). Impacts of flooding on the quality of life in rural regions of Southern Slovakia. Applied Research 
in Quality of Life, 11, 221-237. DOI: https://doi.org/10.1007/s11482-014-9363-x. LAYARD, R. (2005). Happiness. Lessons from a new science. New York (Penguin Books). MURGAŠ, F. (2009). Kvalita života a jej priestorová diferenciácia v okresoch Slovenska. Geografický časopis, 61, 121-138.

MURGAŠ, F. (2016). Geographical Conceptualisation of Quality of Life. Ekológia (Bratislava), 35, 309-319.

MURGAŠ, F. (2019). Can Easterlin's paradox be applied to the development of satisfaction with life or does the explanation lie in cultural geographical characteristics? Geografický časopis, 71, 3-14. DOI: https://doi./10.31577/geogrcas.2019.71.1.01.

MURGAŠ F., BÖHM, H. (2015). Environmental indicators for the assessment of quality of life. $15^{\text {th }}$ International Multidisciplinary Scientific Geoconference SGEM 2015, Varna, 18 - 24 June 2015. Conference proceeding. Book 5, Vol. Part A, pp. 251-258.

MURGAS̆, F., KLOBUČNIK, M. (2016). Does quality of place affect well-being? Ekológia (Bratislava), 35, 224-239. DOI: https://doi.org.10.1515/eko-2016-0018.

MURRAY, P. (2020). New Jersey: Pandemic spurs positive quality of life views. West Long Branch, NJ (Monmouth University Poll), [Online]. Available: https:// www.monmouth.edu/polling-institute/documents/monmouthpoll_nj_042920.pdf/ [Accessed 3 May 2020].

NYGAARD, E., TROND, H. (2012). World assumptions, posttraumatic stress and quality of life after a natural disaster: A longitudinal study. Health and Quality of Life Outcomes, 10, 76. DOI: https://doi.org/10.1186/1477-7525-10-76.

OECD (2020). Better Life Index, [Online]. Available: http://www.oecdbetterlifeindex.org/ \#/11111111111 [Accessed 25 February 2020].

PAPANIKOLAOU, V., ADAMIS, D., KYRIOPOULOS, J. (2012). Long term quality of life after a wildfire disaster in a rural part of Greece. Open Journal of Psychiatry, 2012, 2, 164-170 DOI: http://dx.doi.org/10.4236/ojpsych.2012.22022.

PETROVIČ, F., STRÁNOVSKÝ, P., MUCHOVÁ, Z., FALT̃AN, V., SKOKANOVÁ, H., HAVLÍCEK, M., GÁBOR, M., ŚPULEROVÁ, J. (2017). Landscape-ecological optimization of hydric potential in foothills region with dispersed settlements - A case study of Nová Bošáca, Slovakia. Applied Ecology and Environmental, 15(1), 379-400. DOI: http://dx.doi.org/10.15666/aeer/1501 379400.

PETROVIČ, F., MURGAŠ, F. (2020). Holistic and Sustainable quality of life. Conceptualization and application. Folia Geographica, 62, 77-94.

RIŠOVÁ, K., POUŠ, R. (2018). Urban facilities in the quality of life research: a case study of Banská Bystrica city (Central Slovakia). Geografický časopis, 70, 99-116. DOI: https://.doi.org/10.31577/geogrcas.2018.70.2.06.

SASSI P. (2016) Built environment sustainability and quality of life (BESQoL) assessment methodology. In Leal Filho W., Brandli L., eds. Engaging stakeholders in education for sustainable development at university level. World Sustainability Series. Cham (Springer). DOI: https://doi.org/10.1007/978-3-319-26734-0_2.

STEM (2019). Polistopadový vývoj hodnotí pozitivně nejvíce lidí od rok̄u 1992, výrazné rozdily v názoru na polistopadový vývoj však přetrvávají, [Online]. Available: https:// www.stem.cz/ polistopadovy-vyvoj-hodnoti-pozitivne-nejvice-lidi-od-roku-1992-vyraz ne-rozdily-v-nazoru-na-polistopadovy-vyvoj-vsak-pretrvavaji// [Accessed 6 March 2020].

STREIMIKIENE, D. (2014). Comparative assessment of environmental indicators of quality of life in Romania and Lithuania. Economics \& Sociology, 7, 11-21. DOI: 10.14254/2071-789X.2014/7-1/2.

VEENHOVEN, R. (2000). The four qualities of life: Ordering concepts and measures of the good life. Journal of Happiness Studies, 1, 1-39. DOI: 10.1007/978-94-007-5702811 .

ZIMM̄ERER, K. S. (2017). Geography and the study of human - environment relations. In Richardson, D., ed. International encyclopedia of geography: People, the earth, environment, and technology. Hoboken, NJ (Wiley), 1-23. DOI: https://doi.org/10.1002/ 9781118786352.wbieg1028. 
František Murga š, František Pe trovič

\section{KVALITA ŽIVOTA A KVALITA PROSTREDIA V ČESKU V OBDOBÍ PANDÉMIE COVID-19}

V jarných mesiacoch roku 2020 prepukla epidémia respiračného ochorenia, ktoré dostalo označenie COVID-19. Počas krátkeho obdobia postihla temer všetky krajiny Zeme, takže ju WHO označila za pandémiu. Rast počtu nakazených a mŕtvych spolu s neexistenciou vakcíny a nedostatkom účinných pomôcok viedli vlády $\mathrm{k}$ prijímaniu tvrdých opatrení. Výučba na všetkých typoch škôl vrátane univerzít bola prerušená, obchody s výnimkou potravín, drogérií, lekární a benzínových púmp boli zatvorené. Všetky hromadné športové a iné akcie vrátane omší boli zrušené, medzištátna doprava prestala existovat'. Priemyselné podniky prestali vyrábat' a cestovný ruch takmer prestal existovat'.

Tieto opatrenia vlád spôsobili najväčšiu zmenu sociálneho a ekonomického života od konca 2. svetovej vojny. V článku sa zaoberáme dosahom týchto zmien na kvalitu života a kvalitu prostredia. Doterajší výskum dosahov prírodných katastrof priniesol poznanie poklesu kvality života obyvatel'ov, ktorých sa tieto pohromy týkali. V tomto zmysle sme formulovali hypotézu: Očakávame, že úzkost', obavy a depresie sprevádzajúce súčasnú pandémiu sa prejavia $\mathrm{v}$ nižšom, v niektorých prípadoch nízkom hodnotení kvality života obyvatel'ov. Výskum prebiehal v Českej republike $(\mathrm{N}=311)$ u obyvatel'ov starších ako 18 rokov. Na meranie kvality života a súvisiacich fenoménov bol zostavený dotazník s väčšinou otázok kvantifikovatel'ných na škále $0-10$.

Meranie kvality života a kvality prostredia v čase pandémie ochorenia COVID-19 prinieslo prekvapivé výsledky.

1) Kvalita života mužov i žien je vysoká, hypotéza sa nepotvrdila.

2) Priemerná hodnota kvality života $(7,65)$ je nepatrne nižšia ako priemerná hodnota kvality života $(7,74)$ meraná v roku 2019.

3) Kvalita života žien $(7,93)$ je vyššia ako kvalita života mužov $(7,38)$. Toto konštatovanie platí aj pri ostatných skúmaných pramenných.

4) Kvalita prostredia $(7,67)$ je vyššia ako priemerná hodnota kvality prostredia meraná $\mathrm{v}$ roku $2019(7,16)$.

Meranie kvality života v období pandémie COVID-19 v d’alších krajinách ukáže, či sú vysoké hodnoty namerané v Česku ojedinelé, alebo zlepšovanie kvality života vo vyspelých krajinách neprerušila ani pandémia.

Article first received: May 2020

Article accepted: August 2020 